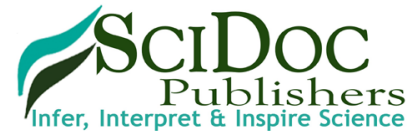

International Journal of Forensic Science \& Pathology (IJFP) ISSN 2332-287X

\title{
Study of Insect Larva Used to Detect Toxic Substance through Decomposed Bodies
}

Anuradha Samnol ${ }^{1}$, Rajeev Kumar ${ }^{2}$, Mahipal Singh S ${ }^{3 *}$, Kapil Parihar ${ }^{3}$

${ }^{1}$ Student of M.Sc. Forensic Science, Division of Forensic Science, SBAS, Galgotias University,Greater Noida, U.P., India.

${ }^{2}$ Associate Professor, Division of Forensic Science, SBAS, Galgotias University, Greater Noida, U.P., India.

${ }^{3}$ Research Scholars, Division of Forensic Science, SBAS, Galgotias University,Greater Noida, U.P., India.

\section{Abstract}

Forensic entomology, Entomotoxicology is used to study the effect of toxins in the cadaver with the help of the insects. In some cases when toxicological samples are absent then the insects and other arthropods plays an important role to study the time since death and also the postmortem index (PMI). The identification and quantification of the present drug in the cadaver is studied through the analysis of the insects and other feeding arthropods present on the cadaver. The presence of different types of drug viz; benzodiazepines, nefopam, antidepressants, opiates, cocaine, heroin, barbiturates, alcohol etc. can also be identified through the study of insect larvae. Entomotoxicology is also used to establish the comparative study between the drugged and non-drugged bodies and the larvae samples collected, preserved in ethanol and used as controlled samples in laboratories.

Keywords: Entomotoxicology; Cadaver; Insects; Arthropods.

\section{Introduction}

Forensic Entomology is the use of the insects and other arthropods that feed on decaying remains to aid legal investigations [15]. Medico legal entomology is a branch of forensic entomology that use of the familiarity of arthropod in investigations of crimes and legal matters. Entomotoxicology explains the use of toxins in arthropods i.e. flies and beetles that develop on cadaver. The insect evidence study plays important role for forensic and legal purposes. Insect study offer numerous knowledge about delinquencies. Insect studies also used use to estimate the PMI and Time Since Death of a putrefying cadaver. In entomology insect larvae usually used for the determinationof postmortem interval and can be used as analter method for drug determination and suggested when samples such as urine, blood or internal organs are absent. Temperature within a cadaver effects the growth rate of insects that grow on them. Death cases due to drug over indulges increases many times from passed few years. Most of the deaths are exposed after a long period of time and it is not rare that the cadaver could be highly putrefied or skeletonized. Under such conditions, the tissues are not available for the analysis.
Hence the identification of toxins, made possible by from the study of insect skin, larvae, and pupa present near to the cadaver. The identification of drug from the insects was started from year 1980 and made it useful to solve the crime [19]. The knowledge of resident insect gatherings and their population dynamics is vital for forensic entomologists. Entomotoxicology deals with the "study of toxins in arthropods (mainly flies and beetles) that feed on carrion. Arthropods are used to identify whether the toxins were present in a body at the time of death or not [13]. Forensic Entomotoxicology also used to study the effects of toxins on the developmental frequency of insects that feeds on the cadaver and also used to study the effects of these toxins on the cadaver when the other cadaver tissues are absent [10]. Almost every entomotoxicological study have their focus on easily available and prescribed drugs. Collected insect specimens from decaying bodies helps forensic entomologists to calculate the minimum post-mortem interval (PMI) and this is the most common application of entomotoxicology in forensic science [9]. The other most important application of forensic entomology is the estimation of the time of death [18]. The new techniques used in present time helps the scientists in this field to gather completely grown entomo-

\footnotetext{
*Corresponding Author

Mahipal Singh Sankhla,

Research Scholar, Division of Forensic Science, SBAS, Galgotias University,Greater Noida, U.P., India.

Email: mahipal4n6@gmail.com

Received: February 12, 2020

Accepted: March 11, 2020

Published: March 18, 2020

Citation: Anuradha Samnol, Rajeev Kumar, Mahipal Singh S, Kapil Parihar. Study of Insect Larva Used to Detect Toxic Substance through Decomposed Bodies. Int J Forensic Sci Pathol. 2020;7(1):420-422.

Copyright: Mahipal Singh Sankhla 2020 . This is an open-access article distributed under the terms of the Creative Commons Attribution License, which permits unrestricted use, distribution and reproduction in any medium, provided the original author and source are credited.
} 
logical evidence that can provide all the necessary information's needed for death investigation and helps to answer all the related questions related to the displacement or storage of the remains of the cadaver, time of mutilation, analysis of specific, location of wound, post-mortem pieces on the body, use of drugs (entomotoxicology), linking a suspect to the scene of a crime, sexual misconduct and the identification of accused [5, 6, 10, 13, 25]. Forensic scientists qualitatively and quantitatively classify drugs which may be related to establish the cause and the manner of the death. In most of the crimes, entomotoxicological samples are collected at the time of analysis. On the other hand, if a body is completely decomposed then insect larvae and pupae are collected and examined. The use of insects and their body parts are used as toxicological specimens and is well known. Insects and their parts like pupal cases, frass, etc. can be used to analyze poisons present in decomposing cadaver [5].

\section{Toxicological Samples}

Insects are the first invitees to attack the body once it starts decomposing. A number of different insects and arthropods attacked the dead body due to the strong smelling of the putrefied cadaver. Flies have great powers of dispersion and they rapidly determine bodies, usually ahead of beetles [19]. While these insects can feed on liquid matter that excludes from a fresh body, the flies are unable to absorb the tissues of the fresh cadaver. The commonest insect flies attracted by the dead body are the Blow flies. Yet, many other species of insect flies, beetles and arthropods also found at a death body [10]. The blow flies reach prior in the putrefaction process, they deliver the most precise assessment of time since death [2]. Beetles both their young and completely developed form found on dead bodies. These usually occur at advanced stages of decomposition. When the cadaver dries, it becomes less fit for the blowflies, flesh flies and house flies to develop because they like a semi-liquid environment. The organic materials of entomotoxicological use can be investigated are: larvae, pupae, adult insects, puparial cases, exuviae (cast beetle skins), beetle faecal material (frass), fly predators $[3,4]$. The insects used commonly involved in toxicological studies are true flies (Diptera) and beetles (Coleoptera). Some of the insect species are analyzed completely on which drugs and toxic substances have been recovered successfully. The most obtained insect species are Calliphora vicina and Lucilia sericata [24].

\section{Sample Collection and Preservation}

Insect sampling can be seeming simple but it is the most complex part of forensic Entomotoxicology. Samples collected from the cadaver and from other areas of the body can cause changes of drug absorption in larvae [11]. When the corpse is almost decomposed, investigators must be aware that the collected insects can originate from a source other than the cadaver's body. The succession waves in which the arthropods inhabit the flesh depends on the states of decomposition of the flesh [1]. The sampling sites for drug exposure in insects are the core organs (e.g. liver), the head-area or muscles in cases where no core organs are left. Later the accomplishment of sample collection from the body, they are washed by using normal water and the specimens are freeze for storing at an extreme low temperature lies between $-68^{\circ} \mathrm{F}$ to $39.2^{\circ} \mathrm{F}$. Insect samples are mainly of two types: Organic and Inorganic. Organic samples are initially washed to make them free from human fluids then crushed and subjected to heat at $650^{\circ} \mathrm{C}$ for 24 hours $[12,23,27]$.

\section{Sample Extraction}

The removal of drug from the insect sample offers some advantages with respect to human tissues. From one experiment, it is clear that quantification was not carried out from human tissue due to matrix interferences, while achieved from larvae [18]. Extraction and preparation of larvae samples is similar to human tissue samples [20], Liquid-Liquid extraction and solid phase extraction these techniques are used for the extraction of different drugs and poisons detected [14]. Solid phase extraction is stated to give the best organic decomposition from aqueous extracts of entomological specimen $[4,16]$. Various types of sample form and the organized process involved prior to analysis.

\section{Identification of Species}

The ingrowing species are collected from the dead body and allow to mature completely inside the laboratory under the supervision in identical laboratory conditions. Detailed morphological and physiological procedures were used for the identification of in grown and completely grown species. The collected eggs and larvae from putrefied cadaver are identified as Diptera [17], eggs of Lucilia sericata (Meigen) [6] and the identified larvae belongs to Sarcophaga crassipalpis (Macquart), Calliphora vicina [7].

\section{Determination of Post-Mortem Interval}

Forensic entomology has some drawbacks also and one of the important drawbacks of forensic entomology is that the growth rate of the insects is greatly influenced by the atmospheric conditions like temperature, humidity, season, contact to solar radiations, place of the cadaver. Flies are used to evaluate the postmortem interval (PMI) in permissible inquiries, and it is completed by accumulating young larvae, pupa and insects from the body which allows the insect to be recognized, along with its size and stage [2]. The PMI is also established from the insect succession on the cadaver [21]. The growth rate of insect larvae wide-ranging from species to species. Therefore, for estimation of the PMI, the age of larvae is determined through their life cycle. The presence of toxic substances also alters the growth rate of maggots. The first-generation mature flies used to detect the age. They can be recognized by the shrunken wings, and minute abdomen with dull grey colour [26]. As soon as insects colonizing the flesh in a specific area is known, an insect colonizing succession model [8, 22].

\section{Discussion}

Forensic entomology is an fascinating as well as inspiring field. The chief motive of the study is to use the insects and arthropods for the determination of death weather the deceased before death is intoxication or not. Forensic entomology also used to investigate the homicide, suicide, or other unidentified death. Among all this forensic entomology also helps to determine the cause of death and most importantly postmortem interval (PMI). Forensic Entomotoxicology also helps to found the relative study between the intoxicated and sobriety dead bodies. Entomotoxicology is also used to link the crime with the criminal and provide sample in cases of completely putrefied bodies i.e. complete 
absence of body tissues. Time since death can also be identified from entomology by studying the life cycles of feeding maggots. Temperature, humidity plays important role in the growth rate of the insects, the effect of coverings may also effects insect development. The flesh of the cadaver remains has some drugs which on feeding by the insects enters in their body and can be extracted and identified though the analysis of insects. This helps in the identification of cause of death and to solve the crime.

\section{Conclusion}

The aim of forensic Entomotoxicology is to establish the relation between the corpse and the insect. The examination of the insects found on the feeding cadaver helps to classify the cause of death as well as to establish the identity of the victim. The toxicologist gains some information about the use of drug before death from the maggots that feeds the cadaver. Toxicologist also helps to determine the absorption quantity of drug though the insectsso, it is evident from the above discussion that maggots and insects are useful toxicological analysis when other toxicological samples are not present. In India this field is not so progressive and need some more toxicologist for work on this field and highlighted this field in all over the India.

\section{References}

[1]. Amendt J, Krettek R, Zehner R. Forensic entomology. Naturwissenschaften. 2004 Feb; 91(2):51-65. Pubmed PMID: 14991142.

[2]. Byrd JH, Tomberlin JK, editors. Forensic entomology: the utility of arthropods in legal investigations. CRC press; 2019 Nov 27.

[3]. Beyer JC, Enos WF, Stajić M. Drug identification through analysis of maggots. J Forensic Sci. 1980 Apr 1;25(2):411-2.

[4]. Candela RG, Aventaggiato L. The detection of toxic substances in entomological specimens. Int J Leg Med. 2001; 114(4-5):197-203. Pubmed PMID: 11355395

[5]. Campobasso CP, Introna F. The forensic entomologist in the context of the forensic pathologist's role. Forensic Sci Int. 2001 Aug 15;120(1-2):132-9. Pubmed PMID: 11457621

[6]. Campobasso CP, Gherardi M, Caligara M, Sironi L, Introna F. Drug analysis in blowfly larvae and in human tissues: a comparative study. Int J Legal Med. 2004 Aug 1;118(4):210-4.

[7]. Sadler DW, Chuter G, Seneveratne C, Pounder DJ. Barbiturates and analgesics in Calliphora vicina larvae. J Forensic Sci. 1997 Nov;42(6):1214-5. Pubmed PMID: 9397571.

[8]. Davies L. Species composition and larval habitats of blowfly (Calliphoridae) populations in upland areas in England and Wales. Med Vet Entomol. 1990 Jan;4(1):61-8. Pubmed PMID: 2132970.

[9]. Erzincllioĝlu YZ. The application of entomology to forensic medicine. Med- icine, Science and the Law. 1983 Jan;23(1):57-63.

[10]. Goff ML, Lord WD. Entomotoxicology. A new area for forensic investigation. Am J Forensic Med Pathol .1994 Mar; 15(1):51-7. Pubmed PMID: 8166117.

[11]. Gosselin M, Wille SM, Fernandez Mdel M, Di Fazio V, Samyn N, De Boeck G, et al. Entomotoxicology, experimental set up and interpretation for forensic toxicologists. Forensic Sci Int. 2011 May 20;208(1-3):1-9. Pubmed PMID: 21237593.

[12]. Gunn JA, Shelley C, Lewis SW, ToopT, Archer M. The determination of morphine in the larvae of Calliphorastygia using flow injection analysis and HPLC with chemiluminescence detection. J Anal Toxicol. 2006 Oct; 30(8):519-23. Pubmed PMID: 17132246.

[13]. Introna F, Campobasso CP, Goff ML. Entomotoxicology. Forensic Sci Int. 2001 Aug 15;120(1-2):42-7. Pubmed PMID: 11457608.

[14]. Karampela S, Pistos C, Moraitis K, Stoukas V, Papoutsis I, Zorba E, et al. Development and validation of a LC/MS method for the determination of $\Delta$ 9-tetrahydrocannabinol and 11-carboxy- $\Delta 9$-tetrahydrocannabinol in the larvae of the blowfly Lucilia sericata: Forensic applications. Sci Justice. 2015 Dec 1;55(6):472-80.

[15]. Lord WD. Case histories of the use of insects in investigations. Entomology and death: a procedural guide. Joyce's Print Shop, Clemson, SC. 1990:9-37.

[16]. Levine B, Golle M, Smialek JE. An unusual drug death involving maggots. Am J Forensic Med Pathol. 2000 Mar;21(1):59-61. Pubmed PMID: 10739228.

[17]. Wolff M, Builes A, Zapata G, Morales G, Benecke M. Detection of Parathion (O, O-diethyl O-(4-nitrophenyl) phosphorothioate) by HPLC in insects of forensic importance in Medellín, Colombia. Anil Aggrawal's Internet. J For Med Toxicol. 2004;5(1):6-11.

[18]. Nolte KB, Pinder RD, Lord WD. Insect larvae used to detect cocaine poisoning in a decomposed body. 1992 Jul; 37(4):1179-85. Pubmed PMID: 1506834 .

[19]. Payne-Jame J. Encyclopedia of Forensic Medicine and Legal Medicine. 1st edn. New York: Elsevier Publication. 2005;268-269.

[20]. Pounder DJ. Forensic entomo-toxicology. J Forensic Sci Soc. 1991 OctDec;31(4):469-72. Pubmed PMID: 1797976.

[21]. Rivers DB, Dahlem GA. The science of forensic entomology. John Wiley \& Sons; $2014 \mathrm{Feb} 3$.

[22]. Schoenly K, Reid W. Dynamics of heterotrophic succession in carrion arthropod assemblages: discrete seres or a continuum of change?. Oecologia. 1987 Sep 1;73(2):192-202.

[23]. Sadler DW, Fuke C, Court F, Pounder DJ. Drug accumulation and elimination in Calliphoravicina larvae. Forensic Sci Int. 1995 Feb 28;71(3):191-7. Pubmed PMID: 7713458.

[24]. da Silva EI, Wilhelmi B, Villet MH. Forensic entomotoxicology revisitedtowards professional standardisation of study designs. Int J Leg Med. 2017 Sep 1;131(5):1399-412.

[25]. Tracqui A, Keyser-Tracqui C, Kintz P, Ludes B. Entomotoxicology for the forensic toxicologist: much ado about nothing?.Int J Legal Med. 2004 Aug;118(4):194-6. Pubmed PMID: 15164211.

[26]. Tullis K, Goff ML. Arthropod succession in exposed carrion in a tropical rainforest on O'ahu Island, Hawai'i. J Med Entomol. 1987 May 1;24(3):332-9.

[27]. Wolff M, Builes A, Zapata G, Morales G, Benecke M. Detection of Parathion (O, O-diethyl O-(4-nitrophenyl) phosphorothioate) by HPLC in insects of forensic importance in Medellín, Colombia. Anil Aggrawal's. J Forensic Med Toxicol. 2004; 5(1):6-11. 